\title{
Novel OCT findings in choroidal osteoma: brief report
}

\author{
Ricardo Luz Leitão Guerra ${ }^{1 *} \mathbb{0}$, Rafael Cicconi Arantes ${ }^{1}$, Eduardo Ferrari Marback ${ }^{2}$ and Carol L Shields ${ }^{3}$
}

\begin{abstract}
The aim of this article is to report the presence of choroidal loculation of fluid and choroidal cavern in a case of choroidal osteoma, previously undescribed in this disease.
\end{abstract}

Keywords: Choroidal osteoma, OCT, Optical coherence tomography, Ocular pathology, Choroidal cavern, Choroidal loculation

Dear editor,

Choroidal osteoma is a rare intraocular tumor that can simulate several intraocular conditions. The clinical appearance on fundus examination, aided by ultrasound, are tools for an accurate diagnosis [1].

The evolution of optical coherence tomography (OCT) techniques for choroidal evaluation, such as enhanced depth imaging (EDI), have allowed detailed analysis of choroidal tumors [2].

Intrinsic and unique features of choroidal osteoma hmacular neovascularizationave been described using EDI-OCT such as "subtle horizontal hyperreflective lamellar lines (bone lamella) with occasional denser lines (cement lines), speckled (spongy, cancellous) tissue, and horizontally or vertically oriented tubular channels representing Haversian or Volkman canals or cavernous vascular spaces" [2].

Other researches have also described retinal pigmented epithelium (RPE) and external retinal layer abnormalities in the deossified portion of the tumor [3], subretinal fluid [4], macular neovascularization (MNV) [4], irregular tumor surface [3], focal choroidal excavation [4] and

*Correspondence: ricardo@leitaoguerra.com.b

${ }^{1}$ Retina Department, Leitão Guerra - Oftalmologia, Rua Rio de São Pedro, 256, Bahia 40150-350 Salvador, Brazil

Full list of author information is available at the end of the article osteoma protrusion into the vitreous [4] as OCT findings in choroidal osteoma.

Reviewing the OCT b-scans of a 30-year-old male patient with a large macular choroidal osteoma, we noted two additional OCT findings, previously unreported, including "choroidal loculation of fluid" and RPE tear over "choroidal cavern" (possibly deossified choroidal osteoma) (Fig. 1).

The term "choroidal loculation of fluid" has been used to describe hyporeflective spaces located in the outer choroid with an angular inner border and larger size than the largest choroidal vessels [5]. This finding has been observed in central serous chorioretinopathy (CSC) and has been suggested that it might serve to drive fluid into the sub-RPE and subretinal spaces [5]..

The presence of choroidal loculation of fluid in the present case might be due to the lack of permeability of the choroidal bone tissue. However, the exact mechanism in a single case report might not be representative. We believe that, as hypothesized for CSC, choroidal loculation of fluid can play a role in the presence of subretinal fluid in choroidal osteoma patients without MNV.

"Choroidal caverns" spectrum of lesions is a recent proposed classification of hyporeflective areas within the choroid based on similar morphology and includes intrachoroidal cavitation, choroidal cleft, and choroidal lipid globule caverns [6].

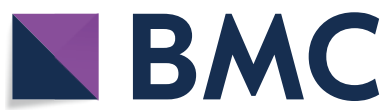

(c) The Author(s) 2021. Open Access This article is licensed under a Creative Commons Attribution 4.0 International License, which permits use, sharing, adaptation, distribution and reproduction in any medium or format, as long as you give appropriate credit to the original author(s) and the source, provide a link to the Creative Commons licence, and indicate if changes were made. The images or other third party material in this article are included in the article's Creative Commons licence, unless indicated otherwise in a credit line to the material. If material is not included in the article's Creative Commons licence and your intended use is not permitted by statutory regulation or exceeds the permitted use, you will need to obtain permission directly from the copyright holder. To view a copy of this licence, visit http://creativecommons.org/licenses/by/4.0/. The Creative Commons Public Domain Dedication waiver (http://creativeco mmons.org/publicdomain/zero/1.0/) applies to the data made available in this article, unless otherwise stated in a credit line to the data. 


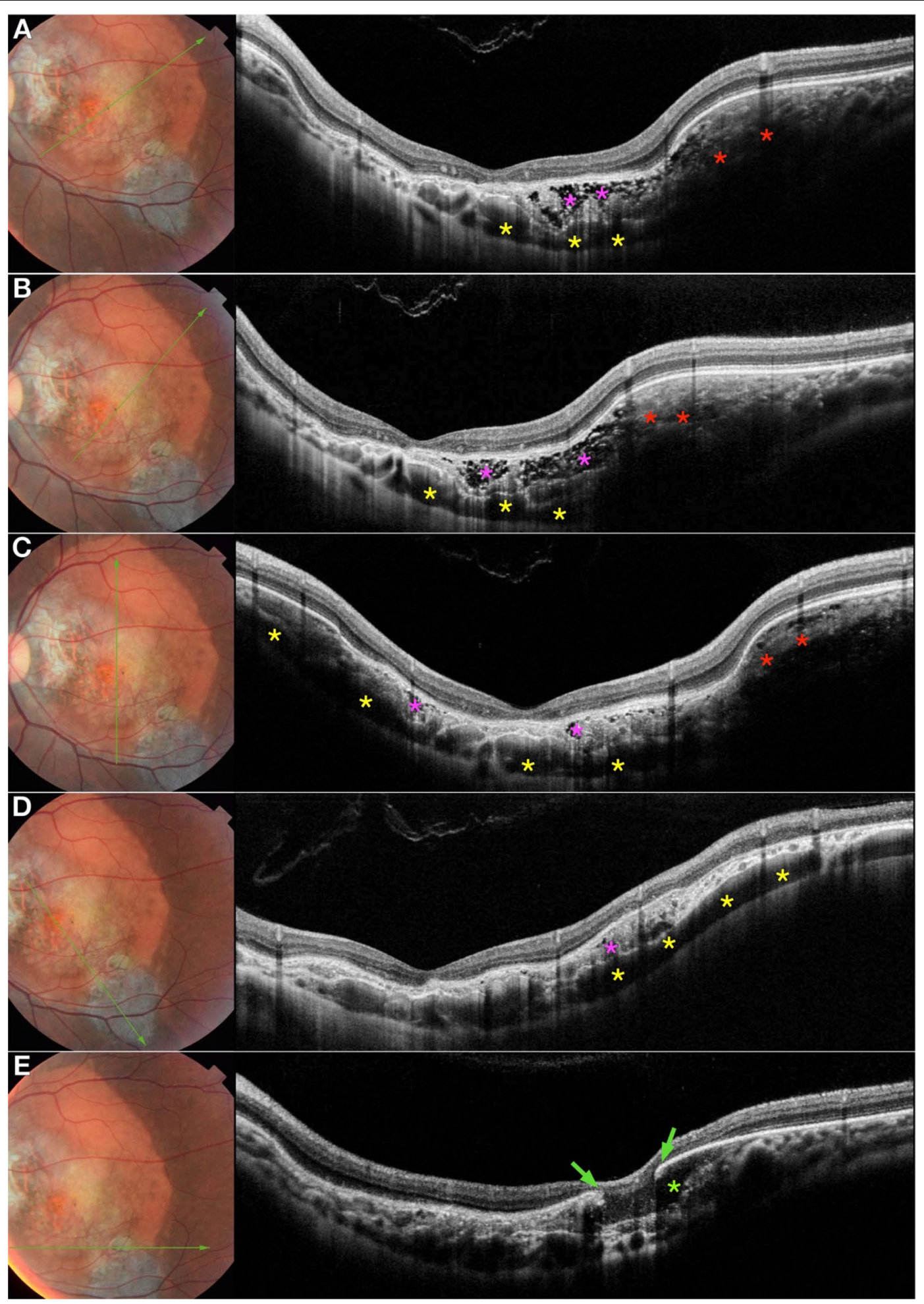

Fig. 1 Enhanced deep imaging optical coherence tomography of a choroidal osteoma. A, B and C Sponge-like appearance in the desossified area (purple asterisk). Lamellar appearance and posterior shadow at the ossified area (red asterisk). Hyporeflective spaces located in the outer choroid corresponding to choroidal loculation (yellow asterisk). D Sponge-like appearance in the desossified area (purple asterisk). Hyporeflective spaces located in the outer choroid corresponding to choroidal loculation (yellow asterisk). E Edges of the retinal pigmented epithelium tear (green arrow) overchoroidal cavern (green asterisk) 
"Speckled hyperreflective dots" found in choroidal osteoma on OCT are suggestive of small trabecular bone tissue [2] and, areas of hyporeflective spaces without hyperreflective dots have been suggestive of areas of presumed osteoclastic activity [1]. In the present case, we observed an overlying RPE tear and cavern and speculate on their origin.

In summary, we would like to highlight these new findings to encourage clinicians to investigate the imaging features and potential pathophysiology of choroidal osteoma.

\section{Abbreviations}

OCT: Optical coherence tomography; EDI: Enhanced depth image; CSC: Central serous corioretinopathy; MNV: Macular neovascularization; RPE: Retinal pigmented epithelium.

\section{Acknowledgements}

Not applicable.

\section{Authors' contributions}

RLLG-design of the work, interpretation of data; RCA-acquisition and data interpretation, review of literature; EFM-interpretation of data, content review; CLS-content review, approved the submitted version; agreed both to be personally accountable for the author's own contributions and to ensure that questions related to the accuracy or integrity of any part of the work, even ones in which the author was not personally involved, are appropriately investigated, resolved, and the resolution documented in the literature. All authors have read and approved the final manuscript.

\section{Funding}

There were no funding sources involved.

\section{Availability of data and materials}

The datasets used and/or analysed during the current study are available from the corresponding author on reasonable request.

\section{Declarations}

Ethics approval and consent to participate

Not applicable.

\section{Consent for publication}

The authors declare to consent the publication of this article.

\section{Competing interests}

The authors declare that they have no competing interests to declare.

\section{Author details}

${ }^{1}$ Retina Department, Leitão Guerra - Oftalmologia, Rua Rio de São Pedro, 256, Bahia 40150-350 Salvador, Brazil. ${ }^{2}$ Ophthalmology Department, Faculdade de Medicina da Bahia, Salvador, Brazil. ${ }^{3}$ Ocular Oncology Department, Wills Eye Hospital, Philadelhia, United States.

Received: 17 May 2021 Accepted: 8 August 2021

Published online: 17 August 2021

\section{References}

1. Azad SV, Kumar V, Chawla R, et al. In vivo optical biopsy of choroidal osteoma: a swept source optical coherence tomography-based tumor characterization. Ther Adv Ophthalmol. 2020;12:251584142092274. https://doi.org/10.1177/2515841420922740.

2. Shields CL, Arepalli S, Atalay HT, Ferenczy SR, Fulco E, Shields JA. Choroidal osteoma shows bone lamella and vascular channels on enhanced depth imaging optical coherence tomographyin 15 eyes. Retina. 2015;35(4):750-7. https://doi.org/10.1097/IAE.0000000000000376.

3. Shields CL, Perez B, Materin MA, Mehta S, Shields JA. Optical coherence tomography of choroidal osteoma in 22 cases. Ophthalmology. 2007;114(12):e53-8. https://doi.org/10.1016/j.ophtha.2007.07.037.

4. Ma F, Li T, Kozak I, Shang Q, Ma J. Novel observations in choroidal osteoma by multispectral imaging: a pilot case series. Int Ophthalmol. 2020;40(12):3413-30. https://doi.org/10.1007/s10792-020-01528-9.

5. Spaide RF, Ryan EH. Loculation of fluid in the posterior choroid in eyes with central serous chorioretinopathy. Am J Ophthalmol. 2015;160(6):1211-6. https://doi.org/10.1016/j.ajo.2015.08.018.

6. Xia Y, Feng N, Hua R. "Choroidal caverns" spectrum lesions. Eye. 2020. https://doi.org/10.1038/s41433-020-1074-y.

\section{Publisher's Note}

Springer Nature remains neutral with regard to jurisdictional claims in published maps and institutional affiliations.

\footnotetext{
Ready to submit your research? Choose BMC and benefit from:

- fast, convenient online submission

- thorough peer review by experienced researchers in your field

- rapid publication on acceptance

- support for research data, including large and complex data types

- gold Open Access which fosters wider collaboration and increased citations

- maximum visibility for your research: over 100M website views per year

At BMC, research is always in progress.

Learn more biomedcentral.com/submissions 